\title{
Quinquennial Terror: Machiavelli’s Understanding of the Political Sublime
}

\author{
Ed King \\ Political Science, Concordia University, Montreal, Canada \\ Email: eking@alcor.concordia.ca
}

Received September $19^{\text {th }}, 2012$; revised February $18^{\text {th }}, 2013$; accepted March $2^{\text {nd }}, 2013$

\begin{abstract}
Copyright (C) 2013 Ed King. This is an open access article distributed under the Creative Commons Attribution License, which permits unrestricted use, distribution, and reproduction in any medium, provided the original work is properly cited.
\end{abstract}

\begin{abstract}
This paper argues that far from advocating fear of violence as a continuous source of civic provocation Machiavelli's ideal ruler employs an aesthetic approach to civic violence; one that actually harms few citizens and moderates their fear with admiration through carefully considered psychological imperatives similar to those articulated two hundred years later in theories of the sublime. Such violence as there was would occur half a decade at a time in between which the citizens and the patria would enjoy stability, wealth and honor. It had a proven Medici provenance, having been developed through Cosimo de Medici's intuitive genius for governance and was maintained by Piero and Lorenzo the Magnificent. The insight was empirically confirmed by Niccolò's observations of similarly intuitive political savants; namely Cesare Borgia and Julius II. It was not given a technical title by Machiavelli, who unhelpfully referred to it as crudeltà bene usate (cruelty well used) but we might call it "the politics of the sublime". Despite its most dramatic (and consequentially disproportionate) evocation in the Prince, Machiavelli’s reliance on the political sublime waned throughout his literary career, until he rejected it in a stunning critique of Cosimo’s reign in the Florentine Histories.
\end{abstract}

Keywords: Machiavelli; Aesthetics; Sublime; Violence; Historical of Public Policy; Medici, Florence

\section{Introduction}

\section{"Machiavelli is excessively pleased by unusual and violent remedies.”}

Historically speaking, Machiavelli's manifest interest in political violence has been viewed by his critics along a continuum extending from immature fascination in violence for its own sake to a belief that violence formed an essential if brutal element in any practical approach to the maintenance of power. His contemporary and friend, Guicciardini, was at the first extreme; in response to Machiavelli's Discourses he advised against taking "for an absolute rule what Machiavelli says, who is always excessively pleased by unusual and violent remedies" (Guicciardini, 1933). The other extreme divides along moral lines that see Machiavelli as offering a criminally negligent authorization of force for the sake of political longevity (Strauss, 1958; Manent, 1995) or an alternative morality that reifies “well used” violence (Von Vacano, 2007; Berlin, 1982). Unfortunately apologists such as Berlin never suggests how violence "well used" is qualitatively, as opposed to strategically distinct from any other violent act, whereas critics such as Strauss and Manent ignore the distinction altogether, perceiving any use of violence for political ends as an evil in itself. Some critical apologists refine their moral concern to focus on Machiavelli's sacrifice of republican principles on the altar of political expediency (Hulliung, 1884; Godman, 1998). While those who lean towards approbation justify Machiavelli's harsh pragmatism by noting that Machiavelli makes his most shock- ing suggestions exclusively to rulers, and excludes citizens from their application (King, 2008).

What these commentators share is a more or less monological understanding of the application, reception, and impact of the violence offered up by Machiavelli's exemplars. It is cruel, brutal and overwhelming; being applied swiftly-without consideration for age, gender or religious principles-and mercilessly to anyone opposed the ruler's designs. The implication is that once applied, such violence requires constant and active maintenance in order to instill a continuous state of fear and trepidation in the subject population. While such violent governance was not unknown in Renaissance Europe, I argue that such an application is not, and never was Machiavelli's design. His ideally violent actor employs an altogether more subtle, not to say aesthetic approach to civic violence; one that actually harms few citizens and moderates their fear with admiration through carefully considered psychological imperatives. Singleton argues that by focusing on aesthetics rather than ethics Machiavelli appropriates Aristotle's conception of "making", which aims at a non-moral artefact, rather than "doing” which seeks to internalize a "correct” way of living (Singleton, 1953). This amoral perspective allows him to relax his advocacy of state sponsored terror for half a decade at a time while the citizens engage in an economically creative social tension that produces stability, wealth and honor for both prince and patria. It had a proven Medici provenance, having been developed through Cosimo de Medici's intuitive genius for governance and maintained by Piero and Lorenzo the Magnificent. The 
insight was empirically confirmed by Niccolò's extensive reading in the Medici archives as well as his observations of similarly intuitive political savants; namely Cesare Borgia and Julius II. It was not given a technical title by Machiavelli, who generally (and unhelpfully) referred to it as crudeltà (cruelty) in his work. Nevertheless one of his earliest critical readers, Giovanni Botero, recognizing its literary roots in the theories of Longinus, immediately named it "the politics of the sublime" (Kahn, 1994). What is most provocative perhaps is that while the Prince is generally credited with offering tyrants a manual on the most effective control of conquered peoples, it is the "republican" Discourses along with the Florentine Histories that actually show how Cosimo used sublime terror to govern the city of his birth. It is equally provocative but demonstrable that this literary progression from the Prince to the Histories illustrates Machiavelli's waning faith in the efficacy of sublime violence from its height in 1513 to its low-tide mark in 1527.

\section{The Sublime Family Secret}

Although it must be acknowledged that nowhere in his writings does Machiavelli use the word "sublime" to describe the theatrical acts of political violence he advocated, it remains the best word to explain the various phenomena Machiavelli believed would result in civic acquiescence if they were "wellused". Eighteenth century scholars, most especially Edmund Burke and Immanuel Kant, would later complete the theoretical framework by identifying the aesthetic effect generated by spectacles of sublime power. However, the political implications of psychologically inassimilable, aesthetically-based terror had not advanced much beyond the intuitive insights of the successful tyrants of antiquity.

The sublime was present in literary discourse as far back as the Peri Hupsous of Longinus and it had a demonstrable influence on thinkers from the beginning of the cinquecento; openly influencing Machiavelli's contemporary, Michelangelo and his later reader, Botero (Arthos, 1963). It is unlikely that, despite his pretensions to poetry, Machiavelli made the connection between the literary and political sublime himself since he employed no convenient term with which to represent the feelings of awe and terror generated by the sublime. His most common synonyms, crudeltà bene usate (cruelty well-used) and rovina (ruinous destruction) fail to convey to us the psychological effects he assumed would occur, and have consequently led many critics astray. This is because, despite enjoying a brief reappearance in the work of Botero, the aesthetic effect of the sublime was not popularly identified in the terms used here until John Dryden and Nicolas Boileau-Despreaux's work in the 17th century. I am forced to take the consciously anachronistic step of unpacking the concept using the terms adopted in the Enlightenment while recognizing that Machiavelli applied these concepts through the limited lexicon of his experiences.

\section{The "Terrifying" Sublime}

Violent storms, yawning chasms, vast mountain ranges, terrible avalanches, or miraculous religious events, such as the burning bush or the parting of the Red Sea, were all expressions of terrifying power that produced similar psychological reactions in all those that witnessed them. In 1763 Kant systematized these reactions into three categories of the sublime; the terrifying, the noble and the splendid, of which only the former need concern us here (Kant, 1991) ${ }^{1}$. The "terrifying” sublime describes the awe-inspiring terror experienced by witnesses of dramatic vistas or overwhelmingly violent activities. "Whatever is fitted in any sort to excite the ideas of pain, and danger, that is to say, whatever is in any sort terrible, or is conversant about terrible objects, or operates in a manner analogous to terror, is a source of the sublime; that is it is productive of the strongest emotion which the mind is capable of feeling” (Burke, 1990). However, the reaction is qualitatively different than if one were actually in danger from such events; the sublime depends for its effect on the combination of sympathetic horror for the victims and relief at the comparative safety of one's own person from the events witnessed. Joseph Addison had already noted this relationship in his 1712 "Essay on the Pleasures of the Imagination" which was to be influential on both Kant and Burke. "When we look on such hideous Objects, we are not a little pleased to think we are in no Danger of them. We consider them at the same time as Dreadful and Harmless; so that the more Frightful appearance they make the greater is the Pleasure we receive from the sense of our own safety" (Addison, 1978).

\section{The Political Sublime}

As far as political implications are concerned the most important aspect of the terrifying sublime is the relationship between the viewer and the political actor; a reaction that transcends reason, self-interest or filial loyalty. It has often been noted that feeling threatened by extreme violence can cause the witness to identify with the perpetrator. "The dazzled witness then tends to identify with the source, acting as if the constraint emanated not from without, but from within himself” (Kelly, 1998). Witnessing an act of sublime violence has the effect of both terrifying yet at the same time profoundly satisfying the witness. It is this response to the aesthetic effects of violence, committed in the course of political ends, to which we should attach the sobriquet "political sublime".

This terminology no doubt appears peculiarly modern when transported into the renaissance context, yet the Florentine secretary's near contemporaries had no trouble discerning the political point of Machiavelli's interest in sublime violence or the rhetoric he couched it in. Giovanni Botero showed acute appreciation for Machiavelli's political and rhetorical strategies only half a century after his works became generally available. In 1585 he published a pamphlet about the political use of the sublime for Jesuits engaged in the counter-reformation by staging a politics of the sublime (Kahn, 1994).

\section{Sublime Not Bestial Violence}

Botero does not refer to a continuous state of terror when he

${ }^{1}$ Outside of these categories I ignore Kant's conception of the sublime, especially as developed in the Critique of Judgment, as it is impossible to form an understanding of the political sublime using such reasoning. Kant argued that the sublime was an interesting category precisely because it included no human artifacts. Man's role was to be the subjective observer and it was unimaginable that he could create any of the conditions that could reproduce the sublime effect on others. The second and more important problem concerns his devaluing of experience. I endorse Hegel's criticism that Kant continually condemns experience as seeming to be possible rather than actual. In Goldthwaite's words Kant shifts from a "principle of explanation", which is the province of the Observations, to a "principle of conduct" which informs the Critique (Kant, 1991). This move away from the value of empirical observation runs completely counter to Machiavelli's conception of the political value of experience and renders their analyses mutually exclusive. 
cites Machiavelli, being one of the few early readers to recognize that Niccolò disdained terror for its own sake. It was never acceptable for rulers to simply devolve to the level of beasts and the Prince cites Commodus' "cruel and bestial spirit" along with Heliogabalus, Macrinus and Julianus' bestial behavior as being “entirely contemptible” (Machiavelli, 1998). Machiavelli exemplifies the difference between the occasional, restrained and therefore effective use of sublime violence-and the bestial effect of its continual application-in the father and son description of the deeds of Severus and Caracalla.

Severus used leonine force when he moved swiftly against Emperor Julianus, executing him in a sublime act of imperial regicide but then imposed a fox like caution on himself, undertaking no further acts of public violence. "Although the people were overburdened by him, he was always able to rule happily because his virtues made him so admirable in the sight of the soldiers and the people that the latter remained somehow astonished and stupefied, while the former were reverent and satisfied" (Machiavelli, 1998). Severus' son Caracalla on the other hand, despite being a man "who had most excellent parts that made him marvelous in the sight of the people and pleasing to the soldiers" (p. 78) was murdered by a soldier in his own army. "His ferocity and cruelty were so great and unheard of-for after infinite individual killings he had put to death a great part of the people of Rome and all the people of Alexandria - that he became most hateful to all the world" (p. 79). Well used cruelties "are not persisted in but are turned to as much utility for the subjects as one can” (p. 37). Bestial cruelty simply leaves the citizenry perpetually afraid; and unremitting fear leads to hatred, which will eventually lead to death at the hands of one's own people. Thus, the ordinary violence of tyrants is what Machiavelli refers to as

"Cruelties... badly used which, though few in the beginning, rather grow with time than are eliminated. Whoever does otherwise [than eliminating opposition in a single sublime stroke] either through timidity or through bad counsel, is always under necessity to hold a knife in his hands; nor can one ever found himself on his subjects if, because of fresh and continued injuries, they cannot be secure against him. For injuries must be done all together, so that, being tasted less they offend less; and benefits should be done little by little so that they may be tasted better" (38).

In the case of strategic, as opposed to moral, considerations the difference between a badly conceived sublime act and one that is properly understood is entirely determined by the benefit that accrues to the people, not the ruler (38). For those who could enact socially constructive violence in this manner, their "well used" acts mitigated the moral impact of their deeds. Those that overstepped the mark, however, soon discovered that rather than live in permanent fear of a rogue leader, citizens would destroy a bestial leader just as they would destroy a wild animal they could not trust. Properly "staged", strategic violence, on the other hand, had the power to overawe a subject people into accepting one's authority as implicitly or explicitly derived from a supernatural source. These irrationally terrifying acts left all but the immediately affected individual(s) physically unharmed, but shaken and respectful of the apparently divine power of the executor. Such was the reaction of the spectators to Remirro de Lorqua's sublimely violent end at the hands of Duke Valentino, Machiavelli's greatest exemplar of the political sublime.

\section{"Divine” Justice in Cesena}

When Cesare Borgia (Duke Valentino) needed to pacify the rebellious peoples of the Romagna he placed his boyhood friend Remirro de Lorqua, “a cruel and ready man”, in charge of subduing the population.

"In a short time Remirro reduced it to peace and unity, with the very greatest reputation to himself. Then the Duke judged that such excessive authority was not necessary, because he feared that it might become hateful; and he set up a civil court in the middle of the province, with a most excellent president, where each city had its advocate. And because he knew that past rigors had generated some hatred for Remirro, to purge the spirits of that people and to gain them entirely to himself, he wished to show that if any cruelty had been committed, this had not come from him but had come from his minister. And having seized this opportunity, he had him placed one morning in the piazza at Cesena in two pieces, with a piece of wood and a bloody knife beside him. The ferocity of this spectacle left the people at once satisfied and stupefied” (Machiavelli, 1998).

Machiavelli was content to record the actions of his sublime hero without explanation. This has important rhetorical implications; since if one were able to rationally analyze the effect one would necessarily give undue prominence to reason's promise of a definitive answer to the paradox of safety through fear. In the political realm, where even Kant admits "the little force which the universal moral feeling would exercise over most hearts” (Kant, 1991), this failure of the imagination presents the ordinary citizen not with the incentive to seek rational answers but rather with their failure to comprehend the cause as rational at all, leading to their assumption of the source of the ruler's power as divine ${ }^{2}$. By presenting their sublime deeds without comment Machiavelli allows his exemplars' deeds to speak for themselves. This is typologically indicative of the prince's assumption of the divine in his political actions, since the actions of gods do not require words to create their effect (King, 2008). The only words involved in the recorded deeds of gods are those spent on the interpretation of their divine acts by their followers. This cultivation of a leader's silence for political effect was exemplified by Cesare Borgia, who in addition to his spectacular acts of theatrical violence often left camp without explanation, rarely made his plans known even to his closest advisors and relished the anxiety his activities caused in the hearts of those, like Machiavelli, whose job it was to divine his "divine" plans for the benefit of the states they served.

The most insightful commentators on Machiavelli occasionally intuit the sublime effect without isolating it as a political tool he consciously advocated. Wayne Rebhorn, who never uses the term "sublime" in his analysis of Machiavelli, describes the effects on the viewer every bit as insightfully as Addison or Burke. "As he has Borgia manipulate the traditional rituals of execution, create a silent, mysterious, compelling emblem, and

\footnotetext{
${ }^{2}$ For Kant the sublime causes the failure of the imagination to comprehend sensuous experience. This failure leads to the demand for comprehension on the part of reason and thus to an awareness of reason as a higher faculty that transcends mere nature.
} 
paradoxically appear both present and distant from the scene, he makes this ideal prince into a figure of overwhelming power for the citizens of Cesena. Indeed Borgia becomes nearly God like” (Rebhorn, 1998).

The "prize" for successfully employing the political sublime was quiescent citizens who were more than simply afraid; they were awestruck, socially unified and collectively devoted to your cause. The "price" lay in the fact that in order to appear to wield divine power, a ruler's sublime acts had to walk the knife's edge between incomprehensibly irrational violence that transcends the rationally causal limits of strategic governance; while never over-indulging in the terrifying cruelty of the savage beast that such power invites. A more immediate cost however, is that once abandoned, the prince can never again enjoy the comforts of ordinary family life under the rule of law.

This is typologically signified by Machiavelli's choice of Moses, Theseus, Romulus and Cyrus, who were all either foundlings or lost their parents early in their lives. The very trauma that disrupted their private lives became a formative feature of their political success. Hannah Pitkin notes that "throughout all the many and complex things Machiavelli has to say about those founders and heroes, a single theme is fundamental: the founder's exceptional personal autonomy. He stands out, he stands alone” (Pitkin, 1984). By living above the law these leaders stand outside of the protective comforts of the state, since, as Aristotle had already noted, "anyone who by his nature and not simply by ill luck has no state is either too bad or too good, either subhuman or superhuman” (Aristotle, 1981). This includes the man who opts to leave the security of the political institution he is born into of his own freewill; he too will necessarily become either an animal or a god.

The ubiquitous use of the political sublime by all of the heroic exemplars in the Prince illustrates Machiavelli's belief that a different rule system applies when a prince decides to voluntarily leave the realm of ordinary citizens (Machiavelli, 1998b). "Free not only from the pressure of custom and tradition, the prince enjoys a more profound and disturbing freedom, a freedom from allegiance to the conventional moral system of his society” (Rebhorn, 1998). Even so, if a prince is established, or lacks the necessary virtù to achieve success, which was increasingly the case in Florence as the memory of the republic lost its potency, then the irony that his name will be cast into obscurity or infamy while that of his family retains the stain of his failure for as long as people remember becomes increasingly relevant.

\section{Agathocles and Cosimo's Sublime Tyranny}

Chapter VIII is the only chapter in which Machiavelli discusses the appropriate application of sublime crudeltà rather than simply announcing or presenting examples of it. Following on directly from the dissection of de Lorqua it presents Agathocles as an example of "Those who have attained a principality through crimes". There are better examples of sublime heroes manqué in the Prince, such as Duke Valentino, Hannibal, Severus and Caracalla, but Agathocles accomplishes the dual aim of showing that virtù is not contingent upon family background, fortune or high ideals but on will alone while highlighting the fact that successful political ends are judged by the satisfaction of the people not the longevity of the ruler's tenure.

The example of Agathocles shows that, with or without a resort to the sublime, the "will to power" was a necessary but insufficient attribute of a determined prince. The qualities that inform virtù cannot be even instrumentally effective without $\mathrm{a}$ guiding conception of the public good that corrals the corrosive freedom engendered by a prince's extralegal use of his power. Agathocles was capable of extraordinary acts beyond the reach of moral, especially Christian, censure, making him an exemplar with all the necessary attributes but one-he never established a republic — and that fact alone makes him unsuitable for virtuous emulation. Irrespective of his ability to effect acts of sublime political violence, his lack of republican ambition caused him to go down in Machiavelli's narrative as a tragic failure rather than the great founder his qualities clearly marked him out to be. His failure to use sublime violence against external enemies rather than using it to smother internal dissent served as an exemplary warning to the Medici princes not to wield the sublime as their ancestors had done and ignore the larger duty involved in accessing such a powerful force.

Cosimo's public legend was that of a successful and longlived ruler of a peaceful state; the Pater Patriae, father of the fatherland no less. However, Machiavelli's arrabbiati (wrathful) version of Cosimo's story is unique in the Florentine annals for suggesting a sublime root to Medici power before going on to eviscerate the benign paternalism of the legend.

“Those who governed the state of Florence from 1432 up to 1494 used to say, to this purpose, that it was necessary to regain the state every five years; otherwise it was difficult to maintain it. They called regaining the state putting that terror and that fear in men that had been put there in taking it, since at that time they had beaten down those who, according to that mode of life, had worked for ill. but as the memory of that beating is eliminated, men began to dare to try new things and to say evil; and so it is necessary to provide for it, drawing the state back toward its beginnings” (Machiavelli, 1998b).

This is an unequivocal statement to the effect that the Medici ancestors: Cosimo, Piero, and Lorenzo- "those who governed the state of Florence from 1432 up to 1494”- - understood that about once every five years it was necessary to put "that terror and that fear in men that had been put there in taking it”. In other words, the Medici brought peace to Florence by quinquennially carrying out acts terrifying enough to crush the self-interested (read anti-Medici) ambitions of the politically disaffected. This doubly effective policy eliminated personal threats to the regime while simultaneously bringing the citizenry back to the level of awestruck compliance that existed at their patria's founding. However, just as with Agathocles, Cosimo and his progeny spoiled his legacy by employing semi-divine power in the service of his family rather than the commune at large and, instead of bequeathing his heirs a virtuous legacy in a free state, he laid the foundations for the interregnum. So, as he had himself carried through the house after his son's death, he said, sighing, "This is too big a house for so small a family". It distressed the greatness of his spirit that it did not appear to him that he had increased the Florentine empire by an honorable acquisition (Machiavelli, 1990). It takes no great skill at allegorical interpretation to read Florence as the "house" and the Medici as the "small family" while the last line remains as uncompromising a condemnation of Cosimo's accomplishments in office as anything written by his enemies. 


\section{Machiavelli's Ancestral Connection to Florence's Sublime History}

It is worth noting that Machiavelli had a personal interest in the effect of this Medici policy, since one of its earliest targets had been several of his own ancestors who had directly opposed Cosimo's right to authoritatively monopolize violence in Florence. As Machiavelli points out in the Histories, Girolamo d'Angelo Machiavelli (1415-1460) was exiled in 1458 and later executed for his principled opposition to Cosimo's oligarchic policies as well as his periodic use of extra-legal terror to confirm his authority (Machiavelli, 1990). Girolamo taught law at the University of Florence, the same university where his grand nephew Niccolò had recently completed the Histories, and he may well already have been teaching when Bartolomeo Scala and Niccolò's father, Bernardo were completing their legal studies at the studio. Girolamo was an active member of the Florentine Guild of Judges and Notaries where he seems to have become politically active (Atkinson, 2002) and in 1445 he was on a panel tasked with drawing up legal reform (Brown, 1979). He incurred Cosimo's displeasure by calling for a reinstitution of freedom of speech in political debate and took the central role in an anti-Medici protest in 1458. He was arrested, tortured, and then exiled to Avignon for 10 years with his brother Piero and some other citizens. Another brother, Francesco d'Agnolo, was arrested and beheaded the following year (Rubenstein, 1997). In 1460 Girolamo was taken prisoner on charges of being a rebel in Lunigiana and returned to Florence, where he was imprisoned and shortly afterwards died. Although the cause of death is unknown the Medici humanist Giuliano de' Ricci was sure he was (deservedly) strangled (Atkinson, 2002).

\section{Poisoning the Body Politic}

Without a focus on the benefits to the republic, the demands of initiating even a limited number of sublime acts would create a municipal cancer, destroying the health of both the state and the very family that a ruler might try to elevate and protect. Machiavelli makes such a criticism of Cosimo: “...because of the infirmity of his body, he could not bring his former diligence to public or private affairs, so that he saw both being ruined because the city was being destroyed by the citizens and his substance by his agents and his sons" (Machiavelli, 1990). Machiavelli maintained the sickness motif throughout the short life of Cosimo's son, Piero who, "because of the weakness of his body" was declared "little fit for public and private affairs". Indeed, every Medici ruler after Cosimo suffered from poor health and each lived a shorter life than his forbear because of it. The early deaths of Giuliano and Lorenzo, the dedicatees of Machiavelli's Prince, kept the issue of health to the forefront of public speculation, and by 1527 the family's inability to maintain the leader's good health threatened their future governance of the state.

The rhetorical effect of paradoxically framing the Medici (literally "Doctors") through their illnesses was to interpret the leadership as diseased; just as Cosimo bequeathed poor personal health through his flawed genes, he also bequeathed his heirs a deeply flawed political framework of his own design. Sick people have no real choices since they are constrained by the demands that their infirmity imposes on them. Arthritic people are especially locked into singular options with respect to their range of movement and it became convenient for Machiavelli to depict Cosimo as politically arthritic as he was physically. His dismissal of the achievements of Cosimo's tenure is displayed most obviously in the manner in which he skips over nine years of his "reign" in a single sentence in order to emphasize nothing but the disease that finally killed him.

"But Florence continued in its disunions and travails. Disunion began in Cosimo's party in ' 55 , for the causes given, which through his prudence, as we have narrated, were arrested for the timebeing. But when the year '64 came, Cosimo's illness became so serious again that he passed from this life” (Machiavelli, 1990).

During the nine years Machiavelli dismisses with the phrase "for the time being" Cosimo managed to prevent factionalism from breaking out through the power of his will alone and Florence lived in an outward state of peace. The lesson was that if even Cosimo was unable to alter his face to the changing times then his example, which had historically sustained Medici success in the face of their changeable fortunes, should no longer to be thought of as a guaranteed template for political success. Cosimo's time-honored political approach, as with the genetic degeneration of the individuals who attempted to wield it, was weak, disease ridden, and in need of a radical overhaul. Most of Cosimo's problems in government came, ironically enough, with the success of his attempts to prevent the rise of an effective opposition (Machiavelli, 1990). Machiavelli's wonderfully ironic conclusion to the second act of the Medici story was that God was no longer comfortable with the Medici expropriating His sublime power and that unless a republic was established He would re-assume exclusive rights to it.

\section{God's “Retaking” of His Sublime}

The strategic use of violence that had seemed so central to the assumption of political power in the Prince was, a decade later being blamed for Cosimo's post 1455 inflexibility and consequent endangerment of the patria (Machiavelli, 1998b). Machiavelli emphasized the impiety at the core of Cosimo's appropriation of God's power by selectively damning him through his own aphorisms.

When some citizens told him after his return from exile that the city was being spoiled and that was acting against God to send away from it so many men of means, he answered that a city spoiled was better than a city lost, that two lengths of rose cloth made a man of means, and that states were not held with paternosters in hand-which sayings gave matter to his enemies to slander him as a man who loved himself more than his patria and this world more than the other (Machiavelli, 1990).

Machiavelli ends this collection of sayings with the phrase "one could repeat many sayings of his, which will be omitted as unnecessary” (283). So clearly what he has provided us with are only the essential sayings; and what Machiavelli considered essential was the message that Cosimo ensured his own power over patriotic or pious considerations, having been able to appropriate His power with nothing more sacred than "two lengths of rose cloth". He then used that authority to sublimely "spoil" the city every five years to prevent it falling out of his family's hands. Since he no longer had any fear of the power 
wielded by God that power now passed out of his hands and, through Machiavelli's auctorial force as a historian, was symbolically handed back to God. It was this literary retrieval of divine power that accounts for an otherwise extremely uncharacteristic diversion in Book VI of the Histories, in which Machiavelli takes time out of his political perorations to speak of a terrible storm.

This storm, which occurred in 1456, was so powerful that it threatened to bring to an end the sublime splendor that God had harnessed in the creation of the world. It was a supernaturally informed version of the Medician requirement to "retake the state" by putting that terror and that fear in men that had been put there in taking it."

From these clouds so broken and confused, from such furious winds and frequent flashes arose a noise never before heard from any earthquake or thunder of any kind or greatness; from it arose such fear that anyone who heard it judged that the end of the world had come, and that earth, water and the rest of the sky and the world, would return mixed together to its ancient chaos (Machiavelli, 1990).

The ostensible reason given for the tempest was the need to revive the crusade against the Muslims, since the Italians' ardor had dampened appreciably once the Hungarian army slowed their advance. However, "when arms had been put away by men, it appeared that God wished to take them up himself" (270).

God was evidently no longer prepared to allow His divine power to be used for parochial goals such as familial self-promotion when the more pressing mission was to retake Constantinople, which had fallen only three years before. That Machiavelli has God making a politically sublime statement through the elements is clear from his description of the storm's effects, which closely parallel the sublime "regaining" of the city described by Cosimo.

This storm, to those who saw and heard it, [not those who experienced its deadly effects] brought the utmost pity and terror. The purpose of God without doubt was to threaten rather than to punish Tuscany; for if so great a wind had entered a city, among the houses and the thickly crowded inhabitants, as it came among the oaks and trees and houses that were few and scattered, without doubt it would have made the greatest ruin and destruction that the mind can imagine. But God purposed at that time that this slight example should suffice to refresh among men the memory of his power (Machiavelli, 1990).

In this extended example Machiavelli has God confirm how a human prince should act when invoking the sublime; hurting a few so that the many who were not hurt would learn their lesson and comply the more readily with his wishes. "A waggoner, together with his mules, was found dead far from the road in a nearby valley... When the storm passed and day came, men were left altogether stupefied" (270). The effect of this single death, that left the people stupefied, is noticeably in keeping with that gained by Cesare's execution of Remirro de Lorqua or Cosimo's murder of Girolamo. It also echoes Machiavelli's advice in chapter III of the Prince: “And those whom he [the prince] offends since they remain dispersed and poor, can never harm him, while all the others remain on the one hand unhurt, and for this they should be quiet; on the other they are afraid to err from fear that what happened to the despoiled might happen to them (Machiavelli, 1998).

\section{Conclusion}

In 1482 God escalated his opposition to the Medici by sending in His instrument to retake the state from Lorenzo. When one considers the role of Savonarola in Medici history it is easy to imagine a narrative in which he is sent by God to refute Cosimo's boasts. Despite Cosimo's confident claim to the contrary, Savonarola was clearly more politically aware than two yards of cloth alone could make him and in 1482 the city was held in hand by paternosters, at least for long enough to remove the Medici from power. If the logic of this narrative is maintained it was actually God's will, enacted through the sublime power of the Church, that in 1494 brought an end to Medici rule and in 1512 reinstated it again through the intervention of Julius II. Whether the irony was God's or Machiavelli's, by announcing His "regaining" of the power of the sublime Machiavelli signaled the inappropriateness of corrosive political violence as a pedagogical tool for the Medici; except of course, if God's representative, his patron Clement VII, chose to instigate it on His behalf, combining the forces of Church and State in order to unify the whole of Italy.

\section{REFERENCES}

Addison, J. (1978). The miscellaneous works of Joseph Addison. Clair Shores, Michigan.

Aristotle (1981). The Politics. T. A. Sinclair, Trans. London: Penguin Classics.

Atkinson, C. (2002). Debts, dowries, donkeys: The diary of Niccolò Machiavelli's father, Messer Bernardo, in quattrocento Florence. Frankfurt: Peter Lang.

Arthos, J. (1963). Dante, michelangelo and Milton. London: Routledge \& Kegan Paul.

Berlin, I. (1982). The originality of Machiavelli. In H. Hardy (Ed.), Against the current (pp. 25-80). New York: Penguin.

Brown, A. (1979). Bartolomeo scala, chancellor of Florence: 1430 1497. Princeton, NJ: Princeton University Press.

Burke, E. (1990). A philosophical enquiry into the origin of our ideas of the sublime and beautiful. Oxford: Oxford University Press.

Godman, P. (1998). From poliziano to Machiavelli: Florentine humanism in the high renaissance. Princeton, NJ: Princeton University Press.

Guicciardini, F. (1933). Scritti politici e ricordi. Bari: Laterza.

Hulliung, M. (1984). Citizen Machiavelli. Princeton, NJ: Princeton University Press.

Kahn, V. (1994). Machiavellian rhetoric: From the counter-reformation to Milton. Princeton, NJ: Princeton University Press.

Kant, I. (1991). Observations on the feeling of the beautiful and the sublime. J. Goldthwaite, Trans. Berkeley: University of California Press.

Kelly, M. (1998). The encyclopedia of aesthetics. Oxford: Oxford University Press.

King, E. (2008). Machiavelli's L’Asino: Troubled centaur into conscious ass. Canadian Journal of Political Science, 41, 279-301. doi:10.1017/S0008423908080487

Machiavelli, N. (1990). Florentine histories. L. F. Banfield, \& H. C. Mansfield Jr., Trans. Princeton: Princeton University Press.

Machiavelli, N. (1998). The prince. H. C. Mansfield, Trans. Chicago, IL: University Of Chicago Press.

Machiavelli, N. (1998b). Discourses on livy. H. C. Mansfield, \& N. Tarcov, Trans. Chicago, IL: University of Chicago Press.

Manent, P. (1995). An intellectual history of liberalism. R. Balinski, Trans. Princeton, NJ: University of Princeton Press.

Pitkin, H. (1984). Fortune is a woman: Gender and politics in the 


\section{ED KING}

thought of Niccolò Machiavelli. Berkeley: University of California Press.

Rebhorn, W. (1998). Foxes and lions: Machiavelli's confidence men. Ithaca: Cornell University Press.

Rubenstein, N. (1997). The government of Florence under the medici 1434-1494. Oxford: Clarendon Press.

Singleton, C. (1953). The perspective of art. The Kenyon Review, 15,
169-189.

Strauss, L. (1958). Thoughts on Machiavelli. Glencoe, IL: Free Press.

Von Vacano, D. A. (2007). The art of power: Machiavelli, nietzsche, and the making of aesthetic political theory. Lanham, MA: Lexington Books. 